胃癌症例に扣ける術後合併症の検討

\author{
札幌医科大学第 1 外科 \\ 秋山 守文 戸塚 守夫 桂巻 正 白川 拓 \\ 及川 郁雄 小林 謙二 早坂 滉

\section{POSTOPERATIVE COMPLICATIONS AND THEIR PROPHYLAXIS FOR GASTRIC CANCER}

\section{Morifumi AKIYAMA, Morio TOTSUKA, Tadashi KATSURAMAKI, Taku SHIRAKAWA, Ikuo OIKAWA, Kenji KOBAYASHI and Hirohsi HAYASAKA}

1st Department of Surgery, Sapporo Medical College

\begin{abstract}
最近 7 年間の胃癌症例 460 例について術後合併症も分析した。全身合併症としては肺不全が最も多 く, 10 例 $2 \%$ にられ, 術前の肺機能評価の重要性を強調した。局所合併症としては縫合不全が最す 多く24例 $5.2 \%$ major leakage は13例であり 3 例を失っている. 術後腹腔内出血は 4 例であり, らち 2 例は縫合不全に上る膿瘍が原因となった，膵尾・脾合併切除による術後合併症の増加は軽微であっ た，縫合不全が術後合併症として最も重要であり，多喴器不全の初因となりうる．縫合不全の予防に は手術手技の向上はもちろんのこと, 術前術後にわたる低蛋白血症の補正, 吻合部血流の保持など, 術式の選択面についても反省を加光た。
\end{abstract}

索引用語：胃癌術後合併症, 術後肺不全, 縫合不全, 低蛋白血症, 低酸素血症

1.はじめに

最近の術前管理の進歩, 麻酔や手術手技の普遍化に ともない, 術後合併症は隇少してはいるが, 反面, 手 術適応や郭清範囲の拡大，高齢者に対する積極的手術 によって術後合併症は必ずしも大幅な減少をきたした とは言い難い，今回胃癌手術に扮ける術後合併症の発 生状況と，その対策について考察を試みた。

\section{2. 対 象}

1977年から1983年までの 7 年間に経験した胃癌症例 は460例であり，年秢は20歳から97藏までであり，男女 比は2：1で男に多い。このらち何らかの手術の行わ れた457例を対象とした。癌占居部位は A 領域が $42 \%$ ， $\mathrm{M}$ 領域が28\%，C領域16\%，3 領域進行癌が14\%で あった(表 1).

\section{3. 成}

1）全身性合併症としての術後臟器障害

$<1985$ 年 2 月 13 日受理 >別刷請求先：秋山 守文 T060 札幌市中央区南 1 条西16丁目 札幌医科大学 第 1 外科
表 1 胃癌症例

期間 1977年 1983年 7 年間

総数460例 男313例 女147例

\begin{tabular}{c|l|c|r}
\hline 占居部位 & 早期癌 & 進行癌 & \multicolumn{1}{|c}{ 計 } \\
\hline $\mathrm{C}$ 領域 & 11 & 62 & $73(16 \%)$ \\
$\mathrm{M}$ 領域 & 50 & 78 & $128(28 \%)$ \\
$\mathrm{A}$ 領域 & 61 & 133 & $194(42 \%)$ \\
3 領域 & & 65 & $65(14 \%)$ \\
\hline 計 & $122(26.5 \%)$ & $338(73.5 \%)$ & 460 \\
\hline
\end{tabular}

表 2 術後葴器合併症症例数 手術 457例

\begin{tabular}{c|l|l|c}
\hline 占居部位 & \multicolumn{1}{|c|}{ 早期癌 } & 進行癌 & 計 \\
\hline $\mathrm{C}$ & $1 / 11$ & $1 / 62$ & $2 / 73(3 \%)$ \\
$\mathrm{M}$ & $3 / 50$ & $2 / 78$ & $5 / 128(4 \%)$ \\
$\mathrm{A}$ & $1 / 61$ & $4 / 133$ & $5 / 194(2.5 \%)$ \\
3 領域 & & $4 / 62$ & $4 / 62(6.5 \%)$ \\
\hline 計 & $5 / 122(4 \%)$ & $11 / 335(3 \%)$ & $16 / 457(3.5 \%)$ \\
\hline
\end{tabular}


表 3 占居部位・進行度と術後全身合併症件数

\begin{tabular}{|c|c|c|c|c|c|c|c|}
\hline 占居部位 & 例数 & 肺不全 & 肝機能障害 & 心不全 & 腎不全 & DIC & ストレス潰場出血 \\
\hline \multirow{2}{*}{ C } & 早期癌 11 & 1 & & \multirow{7}{*}{1} & \multirow{7}{*}{1} & \multirow{7}{*}{1} & \multirow[b]{7}{*}{1} \\
\hline & 進行癌 62 & 1 & & & & & \\
\hline & 早期癌 50 & 1 & 2 & & & & \\
\hline $\mathrm{M}$ & 進行癌 78 & & 3 & & & & \\
\hline A & 早期癌 61 & & \multirow{3}{*}{2} & & & & \\
\hline A & 進行癌 133 & 4 & & & & & \\
\hline 3 領域 & 進行癌 62 & 3 & & & & & \\
\hline 計 & 457 & 10 & 7 & 1 & 1 & 1 & 1 \\
\hline
\end{tabular}

腹腔内感染症などに直接起因しない葴器合併症は手 術を行った 457 例中16例， $3.5 \%$ に21件発生しており， 癌占居部位では 3 領域を占める高度進行癌に臟器障害 発生率が6.5\% と最も高かった（表 2 ）。肺不全が10例 と最も多く，肝機能障害が 7 例あった(表 3 ). 肺不全 を臨床症状をともない，術後新たに酸素療法を要した もの, X 線写真上無気肺, 胸水が確認されたものとす ると, 術後肺不全の術式は胃全摘 3 例, 噴門側胃切 2 例, B-I 法 2 例, B-II 法 1 例で，胃全摘，噴門側胃切例 に肺不全の合併が多いが，胃腸吻合に終った高度進行 癌の術後にも2 例の肺不全をみている. 肺不全の原因 を推定すると, 術前からの肺機能障害の存在が 5 例, 水分の過㮃投与すなわち尿量の減少の見逃しと思われ るもの 2 例, 過大な手術侵襲 1 例, 原因不明 2 例で平 均年齢67歳であり，全症例の平均59歳より高齢者に肺 不全が発生している. 転㷌はレスピレーターを使用し た 4 例は多臓器不全で失っている，その他の症例は利 尿剂，気管支鏡による去痰，胸腔ドレナージなどで治 㾤している. 肝機能障害を血清ビリルビン $2 \mathrm{mg} / \mathrm{dl}$, GOT, GPT, 100単位以上とすると, 肝機能障害は手 術所要時間や輸血量とも相関なく, 平均年龄56歳と比 較的若い、層に発生している。術前肝障害の既往は23例
であり,このらち 2 例が術後肝機能障害を示した.

2) 局所合併症

手術に起因する腹腔, 胸腔, 腹壁に発生した術後合 併症は 51 例 $11 \%$ に発生した。癌占居部では C 領域癌の 術後に $20 \%$ と多発して扣り，早期癌・進行癌で合併症 発生に差がなかった（表 4 ). minor leakage を含む縫 合不全が 24 例, 手術症例の $5.2 \%$ で最も多く, 術後イレ ウス, 縫合不全に起因しない腹腔内膿䁢が各 5 例あっ た（表 5 ).

萭尾脾合併切除々術後合併症発生件数をみると, 全 体では满脾合併切除例で27/97 (27.8\%), 非合併切除 例 $13.8 \%$ と膵脾合併切除例飞術後合併症発生件数が多 いが(表 6 ), この部が 2 群リンパ節となる C 領域癌,

表 4 腹壁 - 腹腔内胸腔内合併症症例数 手術 457例

\begin{tabular}{c|c|c|c}
\hline 占居部位 & 早期癌 & 進行癌 & 計 \\
\hline $\mathrm{C}$ & $3 / 11(27 \%)$ & $12 / 62(19 \%)$ & $15 / 73(20 \%)$ \\
$\mathrm{M}$ & $5 / 50(10 \%)$ & $7 / 78(9 \%)$ & $12 / 128(9 \%)$ \\
$\mathrm{A}$ & $7 / 61(11 \%)$ & $14 / 133(10 \%)$ & $21 / 194(11 \%)$ \\
3 領域 & & $3 / 62(5 \%)$ & $3 / 62(5 \%)$ \\
\hline 計 & $15 / 122(12 \%)$ & $36 / 335(11 \%)$ & $51 / 457(11 \%)$ \\
\hline
\end{tabular}

表 5 占居部位 - 進行度と局所合併症件数

\begin{tabular}{|c|c|c|c|c|c|c|c|c|c|c|}
\hline 占居部位 & 例数 & 縫合不全 & イレウス & 腹腔感染 & 出 血 & 䐙液漏 & 創哆開 & $\begin{array}{c}\text { 吻合部 } \\
\text { 㹟窘 }\end{array}$ & 腸管穿孔 & その他 \\
\hline \multirow{2}{*}{$\mathrm{C}$} & 早期癌 11 & 2 & & 1 & & \multirow{3}{*}{1} & \multirow{3}{*}{1} & \multirow[b]{2}{*}{1} & \multirow[b]{4}{*}{1} & \multirow[b]{2}{*}{2} \\
\hline & 進行癌 62 & 5 & & 2 & & & & & & \\
\hline \multirow{2}{*}{ M } & 早期癌 50 & 3 & & 1 & & & & 1 & & \\
\hline & 進行癌 78 & 3 & 1 & & & 2 & 1 & & & \\
\hline \multirow{2}{*}{ A } & 早期癌 61 & 2 & 2 & & 1 & & & & & 3 \\
\hline & 進行癌 133 & 6 & 1 & 1 & 3 & & 2 & 2 & 1 & \\
\hline 3 領域 & 進行癌 62 & 3 & 1 & & & & & & 1 & \\
\hline 計 & 457 & 24 & 5 & 5 & 4 & 3 & 4 & 4 & 3 & 5 \\
\hline
\end{tabular}


表 6 苹尾・脾合併切除(PS)の有無之合併症件数

\begin{tabular}{|c|c|c|c|c|}
\hline 占居部位 & & & 合併症総件数 & (藏器不全) \\
\hline \multirow{6}{*}{$\mathrm{C}$ 領域 $17 / 73(23 \%)$} & \multirow[t]{2}{*}{ 早期癌/11(36\%) } & PS $(-)$ & $3 / 7(43 \%)$ & \multirow[t]{3}{*}{$(1 / 7)$} \\
\hline & & $\mathrm{PS}(+)$ & $1 / 4(25 \%)$ & \\
\hline & & & & \\
\hline & \multirow[t]{2}{*}{ 進行癌13/62(21\%) } & $\mathrm{PS}(-)$ & $4 / 34(12 \%)$ & \multirow[t]{2}{*}{$(1 / 34)$} \\
\hline & & $\operatorname{PS}(+)$ & $9 / 28(32 \%)$ & \\
\hline & \multirow[t]{2}{*}{ 早期癌9/50(18\%) } & $\operatorname{PS}(-)$ & $5 / 42(12 \%)$ & $(1 / 42)$ \\
\hline \multirow{4}{*}{ M領域 $20 / 128(15.6 \%)$} & & $\mathrm{PS}(+)$ & $4 / 8(50 \%)$ & $(3 / 8)$ \\
\hline & & & & \\
\hline & \multirow[t]{2}{*}{ 進行癌11/78(14\%) } & $\operatorname{PS}(-)$ & $7 / 50(14 \%)$ & \multirow[t]{2}{*}{$(3 / 50)$} \\
\hline & & $\mathrm{PS}(+)$ & $4 / 28(14 \%)$ & \\
\hline \multirow{4}{*}{$A$ 領域32/194(16.5\%) } & 早期癌 & $\operatorname{PS}(-)$ & $9 / 61(15 \%)$ & $(1 / 61)$ \\
\hline & & & & \\
\hline & \multirow[t]{4}{*}{ 進行癌23/133(17\%) } & $\operatorname{PS}(-)$ & $22 / 132(17 \%)$ & $(6 / 132)$ \\
\hline & & $\operatorname{PS}(+)$ & $1 / 1$ & $(1 / 1)$ \\
\hline \multirow{2}{*}{3 領域進行癌 $8 / 62(13 \%)$} & & $\mathrm{PS}(-)$ & $0 / 34$ & \multirow{2}{*}{$(3 / 28)$} \\
\hline & & PS $(+)$ & $8 / 28(28 \%)$ & \\
\hline
\end{tabular}

$\mathrm{M}$ 領域進行癌をみると, 荤脾合併切除群 $23.3 \%$, 非合 併切除群 $17.3 \%$ と前者に術後合併症が起こりやすい傾 向があるが有意とはいえない。

術式別合併症件数では B-I 法 $17.5 \%$ ， B-II 法30\%, 近位胃切 28 例中，食道胃吻合 $27 \%$ ，食道空腸吻合（空 腸間置法） $30 \% ，$ 胃全摘 Roux-Y 法 $27 \%$ ，同空腸間置 法 $18 \%$ と一定の傾向はみられないが，全摘例では空腸 間置法よりRoux-Y 法に合併症件数が多い（表 7 ).

a) 縫合不全

縫合不全は minor leakage む含め24例であり, 手術 症例の $5.2 \%$ ，胃切除症例の $6.2 \%$ に当る。再建法と释 合不全部位では B-I 法では3.7\%に, B-II 法では十二指

表 7 術式別合併症 件数/症例数

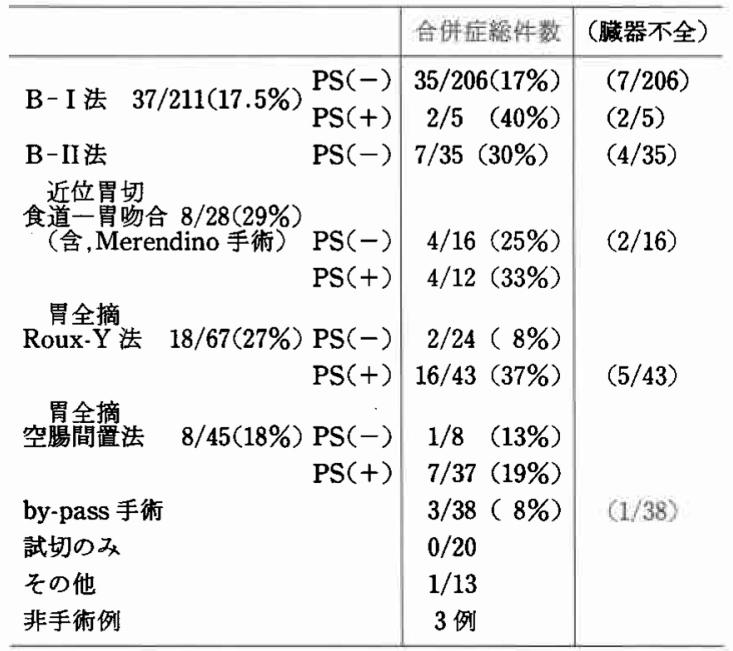

腸に浸潤の及んだ A 領域癌で十二指腸断端に縫合不 全をきたした 1 例のみであった。近位胃切では食道胃 吻合で 1 例，食道・間置空腸吻合に 1 例の縫合不全を みている. 胃全摘例では Roux-Y 法で7.4\%, 空腸間置 法で18\%の縫合不全例をみている（表 8 ）.

縫合不全の原因の考察では必ずしも特定はできない が, minor leakage 11例の 万ち術後 5 日日目から 7 日 目の血清アルブミンが $2.5 \mathrm{~g} / \mathrm{dl}$ 以下の高度の低蛋白血 症 3 例, 追加切除による吻合部過緊張 1 例, 術前加ら の全身合併症に起因するもの 3 例などが考えられるが

表 8 縫合不全症例と再建法

\begin{tabular}{|c|c|c|c|}
\hline $\begin{array}{l}\text { 再建法 } \\
\text { 吻合部位 }\end{array}$ & 主占居部位 & 件数 & \\
\hline \multirow[t]{3}{*}{ - B-I 法 } & & & \multirow{3}{*}{$8 / 211(3.7 \%)$} \\
\hline & M & 2 & \\
\hline & A & 6 & \\
\hline $\begin{array}{l}- \text { B - II 法 } \\
\quad \text { (十二指腸) }\end{array}$ & A & 1 & $1 / 35(3 \%)$ \\
\hline \multirow{2}{*}{$\begin{array}{l}\text { - 食道-胃 } \\
\text { 食道-空腸 } \\
\text { (Merendino) }\end{array}$} & C & 1 & \multirow[t]{2}{*}{$2 / 28(7 \%)$} \\
\hline & $\mathrm{C}$ & 1 & \\
\hline \multirow{3}{*}{$\begin{array}{l}\text { - Roux-Y 法 } \\
\text { （食道-空腸） }\end{array}$} & $\mathrm{C}$ & 2 & \multirow{3}{*}{$5 / 67(7.4 \%)$} \\
\hline & M & 1 & \\
\hline & 3 領域 & 1 & \\
\hline \multirow{5}{*}{$\begin{array}{c}\text { （空腸-空腸） } \\
\text { ・空腸間置法 } \\
\text { (食道-空腸) }\end{array}$} & $\mathbf{M}$ & 1 & \multirow{5}{*}{$8 / 45(18 \%)$} \\
\hline & $\mathrm{C}$ & 3 & \\
\hline & $\mathbf{M}$ & 2 & \\
\hline & A & 1 & \\
\hline & 3 領域 & 2 & \\
\hline 計 & & & $24 / 386(6.2 \%)$ \\
\hline
\end{tabular}


原因不明が 4 例ある. major leakage では低蛋白 4 例, 追加切除に上る過緊張 4 例, 吻合技術の拙劣 3 例など であり, やはり原因不明が 3 例ある(表 9 ). 胃切除後, 経過良好な100例の術前血清総蛋白は6.64 $0.06 \mathrm{~g} /$ $\mathrm{dl}$, アルブミン $3.51 \pm 0.05 \mathrm{~g} / \mathrm{dl}$ であり，ネフローゼ症 候群 1 例を除く23例の縫合不全例ではそれぞれ6.61土 $0.11 \mathrm{~g} / \mathrm{dl}, 3.47 \pm 0.08 \mathrm{~g} / \mathrm{dl}$ とまったく差がなく, 術後 5 日目から 7 日目の経過良好群の血清総蛋白は6.22士 $0.07 \mathrm{~g} / \mathrm{dl}$, アルブミン $3.0 \pm 0.04 \mathrm{~g} / \mathrm{dl}$, 縫合不全例では それぞれ $5.9 \pm 0.12 \mathrm{~g} / \mathrm{dl}, 2.7 \pm 0.06 \mathrm{~g} / \mathrm{dl}$ と縫合不全例 で血清総蛋白, アルブミンとも有意に低下している(表 $10)$.

縫合不全の対策には minor leakage では経口摄取

表 9 縫合不全の原因

\begin{tabular}{|c|c|c|}
\hline \multirow{7}{*}{$\begin{array}{c}\text { minor } \\
\text { leakage } \\
11 \text { 例 }\end{array}$} & 術後高度の低蛋白 & 3 \\
\hline & 追加切除による過緊張吻合条件の悪化 & 1 \\
\hline & 肝硬変の存在 & 1 \\
\hline & 術前からの心不全 & 1 \\
\hline & ネフローゼ症候群 & 1 \\
\hline & ドレンの瓦迫？ & 1 \\
\hline & 原因不明 & 4 \\
\hline \multirow{5}{*}{$\begin{array}{c}\text { major } \\
\text { leakage } \\
\text { 13例 }\end{array}$} & 技術的問題（手縫い） & 3 \\
\hline & 術後高度の低蛋白 & 4 \\
\hline & 追加切除による過緊張, 吻合条件の悪化 & 4 \\
\hline & 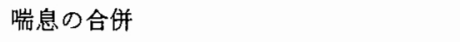 & 1 \\
\hline & 原因不明 & 3 \\
\hline
\end{tabular}

表10 繾合不全例の血清蛋白 $(\mathrm{g} / \mathrm{dl}, \pm \mathrm{SE})$

\begin{tabular}{c|c|c|c|c}
\hline & \multicolumn{2}{|c|}{ 術 } & 前 & \multicolumn{2}{|c}{ 術後 $5-7$ 日目 } \\
\cline { 2 - 5 } & 総蛋白 & アルブミン & 総蛋白 & アルブミン \\
\hline $\begin{array}{c}\text { 経過良好群 } \\
\mathrm{n}=100\end{array}$ & $6.64 \pm 0.06$ & $3.51 \pm 0.05$ & $6.22 \pm 0.07$ & $3.00 \pm 0.04$ \\
N.S. & N.S. & $\mathrm{P}<0.05$ & $\mathrm{P}<0.005$ \\
$\begin{array}{c}\text { 䋖合不全例 } \\
\mathrm{n}=23\end{array}$ & $6.61 \pm 0.11$ & $3.47 \pm 0.08$ & $5.90 \pm 0.12$ & $2.70 \pm 0.06$ \\
\hline
\end{tabular}

表11 縫合不全の対策，予後

\begin{tabular}{|c|c|c|c|}
\hline & 対 & 策 & 治痣に要した日数，転帰 \\
\hline \multirow{3}{*}{$\begin{array}{c}\text { minor } \\
\text { leakage } \\
11 \text { 例 }\end{array}$} & 経口摂取続行 & 2 例 & \\
\hline & TPN & 9 例 & 11 40日治㾍 \\
\hline & TPN & 6 例 & 25～150日治菱 \\
\hline \multirow{3}{*}{$\begin{array}{l}\text { minor } \\
\text { leakage } \\
13 \text { 例 }\end{array}$} & $\mathrm{TPN}+\mathrm{ED}$ & 1 例 & 120 日治恣 \\
\hline & $\begin{array}{l}\text { 再手術, } \\
\text { ドレナージ }\end{array}$ & 4 例 & $\begin{array}{l}2 \text { 例 } 40 \text { 日, } 150 \text { 日治撚 } \\
2 \text { 例 } 31 \text { 日, } 90 \text { 日死 }\end{array}$ \\
\hline & $\begin{array}{l}\text { 再手術, 止血 } \\
\text { 再吻合 }\end{array}$ & 2 例 & $\begin{array}{l}1 \text { 例100日治虑 } \\
1 \text { 例 } 55 \text { 日死 }\end{array}$ \\
\hline
\end{tabular}

を続行して治瘜したもの 2 例，経口摄取を中止し TPN を施行した 9 例では術後40日をでに治瘾してい る. major leakage では TPN で 6 例が治瘾している が，多くの日数を要した。再手術は 6 例に行われてお り，うち 2 例は槰合不全に起因する腹腔内出血で緊急 手術を行っている.縫合不全による死亡は 3 例であり， 手術例の $0.7 \%$ に当る（表11）.

b) 術後出血

胃切除後の出血は 4 例経験している，前述したよう に 2 例が縫合不全から腹腔内感染巣を作り, 膿湟の血 管侵触による大出血をきたしている（表12，症例 1， 2 ). 1 例は脾損傷の出血に自然止血を期待して開腹し たが, 血腫を作り,これに感染が加わり multiple organ failure (MOF) で失っている，他の 1 例（表12，症例 4）は虚血性心疾患之胸膜炎，総胆管結石を有する胃 癌患者で幽門側亜全摘を行ったが，術後 6 日目腹腔ド レンと Tチューブ内に出血があり，再開腹したが出血 点を発見できず, MOF で死亡した。初回手術の過大侵 獎と考兄られる。

c）腸管穿孔

\section{表12 術後出血例}

1. K. I. 73 歳 女

術前併存疾患：高血圧症

手 術：幽門側垔全摘, $\mathrm{B}-\mathrm{I}$ 法. $\mathrm{R}_{2}$ 8 日目創哆開，排膿

再手術：ドレナージ

再手術後17日目 ドレンより大量出血 再々手術：膵頭部前面の止血, B一II法へ

転 埽: 死亡

2. M. H. 66歳 男

術前併存疾患：なし

手 術：噴門側切除，空腸間置術 $R_{2}$

8 日目释合不全確認

14日目左側ドレンより動脈性出血, ショック 再手術：脾動脈根部の破碇を止血, ドレナーシ 転 帰: 治㾍退院

3. S. S. 58 歳 男

術前併存疾患：虚血性心疾患

術 前：幽門側切除, $\mathrm{R}_{0}$

脾損傷に対する止血の不徹底一血腫一感染—MOF

転 䚻: 死亡

4. M. Y. 74歳 男

術前併存疾患: 総胆管結石, 右胸膜炎, 虚血性心疾患

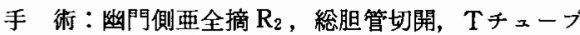
ドレナージ

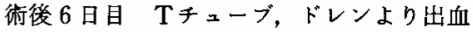
再手術：出血点なし

転 帰: MFO, 死亡 
術後の腸管穿孔は 3 例にみられ，1 例は Roux-Y 法 の食道空腸吻合部に縫合不全を起こし，長期間シリコ ンドレンが留置されたが，縫合不全部が治癒した頃， ドレンKよる圧迫穿孔が食道空腸吻合部の約 $5 \mathrm{~cm}$ 肛 門側の空腸脚に発見された。 1 例は腹腔膿瘍の治撚過 程で横行結腸の穿孔が判明，手術時電気メスによる結 腸壁の凝固壊死の看過したと思われた。残り1例はネ フローゼ症候群の胃切除例で縫合不全をきたし，ドレ ナージは良好であったが，突然一般状態が悪化し，死 亡した。剖検で下行結腸の壊死穿孔が死因と確認され た。

\section{4. 考察}

胃癌手術はそのほとんどが待期的に行われ，術式も 定型化して括り，日常診療上多くの患者は大過なく退 院していくように思える。しかし，軽微な合併症をも 仔細に拾いあげると手術患者の $14 \%$ に何らかの合併症 をみたことになる。

全身合併症で最も多い肺不全は食道噴門部に手術操 作が及んだ例に多いが，高度の進行胃癌や術前すでに 肺合併症を有するものや，肺機能検査で閉塞性障害の あるものでは麻酔や輸液の影響で術後肺不全の発生が 起こりらる，喘息の既往，肺手術歴を有するもの，い わゆる感冒で咳嗽が長びくものなどは要注意であり， 術前に深呼吸の練習を行ら。現在では定量的に吸気運 動を練習する簡単な器具が商品化されている。 るた， 術前に必ず $\mathrm{PaO}_{2}$ を測定し，これを対照とすると術後 の呼吸状態の把握に役立つ. 術後肺不全の予防には水 分の過制投与を避け，略痰溶解剂，抗生物質をネブラ イザーで日に 3，4回吸入させる.聴診上疢の貯溜をみ たら体位変換を行いながら, tapping を強力に行ら。低 酸素血症は創治瘾, 臓器の機能維持にも影響を与える ので酸素療法は積極的に行い，術後早期には少なくと も術前の $\mathrm{PaO}_{2}$ レベルより低くてはいけない, 肺不全 も含め一般状態が悪化していく時は早期にレスピレー ターを使用すべきであり，今回の肺不全例の中にレス ピレーターによる呼吸管理の遅れが死につながったと 思われる症例が 1 例あった。

術後の肝機能障害は麻酔剂, 抗生物質, 静脈栄養の 過剰負荷, 輸血などが原因となりうるが, 原因を特定 することは困難であり，輸血量，侵襲度とは必ずしも 相関しない，今回術前の肝機能障害の既往のあるもの 23 例のらち 2 例飞術後肝機能障害がみられた。 その他 の臓器障害が独自に発生することは胃癌手術後ではま れであった。
腪尾・脾合併切除の有無による術後合併症発生は有 意の差はなく”, 進行癌で 1 群リンパ節に転移が疑わ れる例では積極的に膵脾合併切除を行ってこの部のリ ンパ節郭清を完全なものとすべきである，摘脾が免疫 学的に癌根治の防げになるという確固たる知見はない ようである ${ }^{2}$. また今回の摘脾群で腸管の左横隔膜下 腔への落ち込みによるイレウスは経験していない。

縫合不全は衍中に何らの欠陷も思い当らない場合に も発生し，現在です時には致命的ですらある。胃手術 後の縫合不全の発生頻度は年々減少してきている.胃 切除よりも胃全摘時に多く，やはり食道と胃あるいは 空腸との吻合部に多い。胃全摘で 4 〜 18\%の縫合不全 率が報告されている3) ?

腸管の創傷治瘱過程は吻合部に炎症細胞とフィブリ ンの集積が起き，コラゲンが分解される破壊期と，相 前後して新しいコラダンが産生され始まる增殖期から 成り, 吻合後 3 日から 4 日は組織としての抗張力は得 られず縫合系のみによって組織結合が行われている (lag phase $)^{8)}$ 。この時期に吻合部の感染，血流障害， 過緊張が加わると lag phase が要延し, 縫合不全の危 険が増す。当科でも縫合不全は 5 日目から10日目に発 見され， minor leakage では消化管の術後造影ではじ めて発見されることも多い. major leakage では消化 管内容のドレンからの流出や高熱の遷延, 白血球増多 などがみられる.当科では B-I 法で 8 例 $3.7 \%$ の縫合不 全で major leakage は2 例であった. B-II 法による槰 合不全部は十二指腸断端であり，幽門を越えて癌浸潤 をみた例であった，胃全摘例では Roux-Y 法による再 建で 5 例 $7.4 \%$, 空腸間置法で 8 例 $18 \%$ に縫合不全を越 している. 合併症件数全体では Roux-Y 法 $27 \%$, 空腸 間置法 $18 \%$ と前者の方がより多くの合併症をきたして いる(表 7)。これは術式の選択に，空腸間置法は年龄 が比較的若く，術前に合併症を有せず，かつ根治性が 期待できる症例に適応としており，Roux-Y 法は高龄 者や術前合併疾患を有する患者，根治性にやや難点の ある症例に施行しているので，このような背景因子の 差が術後合併症の発生に表われたと考えているが，縫 合不全だけに注目すると空腸間置法の方が発生率が高 い.この原因としてやはり吻合部の血行不全が起きや すいのではないかと思われる，吊り上げ空腸脚の腸間 膜根部で静脈㷌来の障害が Roux-Y 法より起こりや すいのではないか子考えている，胃全摘13例の縫合不 全は，1例を除きほとんどが食道との吻合部に縫合不 全をきたしている、第 1 吻合部に縫合不全が多いのば 
他の報告と同じである，当科では食道空腸吻合は原則 的に端々吻合をして批，吻合部血行の面では端側吻 合より不利ではないかと思われ，端側吻合を含めて吻 合手技について，再検討中である").

縫合不全の原因の追求はとりもなおさず䂆防につな がるわけであるが，第 1 に血流が良好であることが必 要であり, 食道空腸吻合は端々よりも端側吻合の方が 空腸側の血行障害は少ないと考える，食道は元来血流 の乏しい臟器であるのでより注意が必要であることが 今回の成績でも示されている。しかし血流が良すぎて も思わ妷敗を招くことがある．吻合部に血的を作る ことがあるからである，とくに食道・胃吻合の EEAに よる器械吻合時には，円筒刃で打ち抜かれる吻合口に 当る部に拍動している動脈がある時, 器械吻合部に出 血や血腫を作り，縫合不全の原因と成り得る，われわ れはEEAによる吻合部血腫を経験しているし，低位 前方切除術では内腔より直視下に拍動性出血を認めた こともある. 吻合部の過緊張は血流不全をきたし, major leakage の原因となる. とくに食道側の追加切

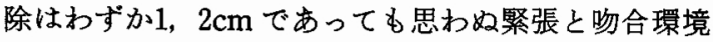
の悪化を招く．われわれは食道胃あるいは食道空腸吻 合終了後, 食道壁と横隔膜脚とを数針縫合固定し, 食 道の緃隔内陥入を防ぎ,吻合部の緊張を軽減している. 逆に食道の緊張の強いときは，むしろ吻合部を糈隔内 に抽し込むよらにして腸管も十分たるませて报く，器 械吻合では器械の構造をよく熟知して慣れることが大 事であり，器械を引き抜く時，吻合部に無理がかから 様, 裂傷を起こさぬ様細心の注意をはらら，打ち拡 かれた腸管の環状性を確認するだけでなく, 前後左右 壁の識別をできるようにしておき，もし粘膜や外膜， 浆膜に欠損の疑われる時は吻合部のその位置に追加縫 合を加光る。

低蛋白血症は吻合部のコラゲンの増殖に影響を与 え, 縫合不全の原因となる ${ }^{10)}$. 今回の集計でも縫合不全 が起こった患者の血清蛋白は経過良好群より平均值が 低かった。しかし，血清蛋白が正常域でる縫合不全は 起こっている，縫合不全が起こると異化克進によって 血清蛋白は低下するが，今回のわれわれの数値(表10) は縫合不全が発現する前のものであり, 術後に一般的 にみられる低蛋白血症がより高度に起こったことが， 縫合不全の一因となったものと考劣ている。また，吻 合部 $\mathrm{PaO}_{2}$ を高めに保つことも縫合不全の予防に大切 であり，少なくとも $\mathrm{PaO}_{2}$ を術前值以下には下げない ことを目標にしている.縫合不全の予防に関する術前,
表13 縫合不全の予防

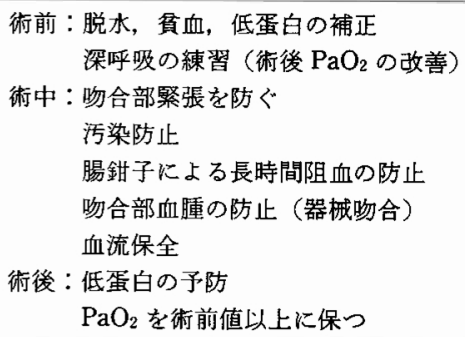

術後にわたる臨床的留意事項を表13にまとめた。

胃癌手術において, 術後出血で術当日の再開腹とい ら事態は最近では皆無といってよい。しかし, 手術侵 襲の増大によって出血素因をきたすことはむしろ多く なっている，これは特定の出血点はなく，手術による 線溶六進や赤血球輸血による凝固因子の希釈による dilution coagulopathy ${ }^{11}$ によることが多く，DICをき たすことは多くはない，DIC は縫合不全などの感染症 の遷延によって起こる ${ }^{12)}$. 胃癌の術後の腹腔内出血は 他の合併病変の結果として起こってくることが多く， 考えられる病態は縫合不全に起因する膿瘍による血管 侵蝕 ${ }^{13)}$, ドレンによる血管の圧迫壊死など特殊な場合 である ${ }^{14)}$.とくに膿瘍が茦を侵蝕する時, 膵酵素によっ て大血管が相乗的に侵蝕されることを考虑しなければ ならない，したがって出血の起こってくる時期は術後 比較的遅く, 術後 6 日目以降の腹腔内出血は縫合不全

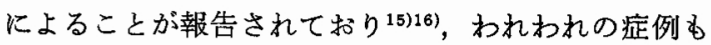
14日目，25日目に大量出血をきたした。縫合不全から 腹腔内出血をきたすような時は，ドレナージが効果的 でないことが多いので，再手術では止血とともに十分 なドレナージ，経腸栄養路の確保などを行う。

腸管穿孔は手術患者の高齢化にともない，血管の非 閉塞性腸壊死によるすのが報告されている17)，われわ れはドレンによる腸の壊死穿孔を経験しているが，ド レンの位置は吻合部の手前に置き，ドレンそのものに よる縫合不全の発生をさたさない上う注意している。 電気入スの使用には十分注意し，腸管壁に誤って触れ た時はその部を縫縮する必要がある. intestinal angina といわれる非閉塞性腸管虚血 ${ }^{18)}$ が認識されてお り, 術後は血液粘度の上昇をきたす輸血の過㮃には注 意を要する。立た, 摘脾後の血小板增多には抗凝固療 法も考慮しなければならない。

\section{5. おわりに}

待期的に行われる胃癌手術でも, 術後合併症を仔細 
に拾いあげると意外と多いことに驚く。なかでる縫合 不全と肺合併症が多く, 時としてはMOF へ移行し致

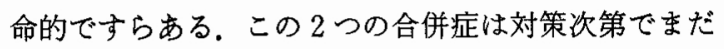
まだ防止しえるものと思われた，今後ますすす普及す る消化管器械吻合の操作にも誰もが習熟する必要があ るが，それ以前に基本的な手術手技をおろそかにして はいけないことは自明の理である。手術患者の高齢化 にともない, 術前のリスク評価を確実にし, 根治性を 損らことなく，かつ術後合併症の减少に努めることが 大切である.

本論文の要旨は第24回日本消化器外科学会総会 (1984年 7 月京都) にて発表した。

\section{文献}

1）宮下 蒘, 武藤輝一, 佐々木公一汸か：上部胃癌に 対する摘脾の意義一脾門リンパ節転移の実態を中 心に一. 日消外会誌 $17: 1086,1984$

2）丸山圭一：胃全摘術に打訬る化臟器合併切除。胃 癌の臨床．東京，へるす出版，1983，p514-536

3）佐藤寿雄, 小山研二, 武藤 功注か：術後缝合不全 一特にその対策について一. 手術 $23: 331-339$, 1970

4）山崎忠光, 高田方悬, 横田広夫ほか：胃全剔術後の 縫合不全の検討およびその予防対策について. 外 科診療 39:129-134, 1978

5）神前五郎：消化管縫合不全の予防と対答. 胃全摘 出後. 外科診療 $19: 1029-1033,1977$

6）西 满正, 加治佐隆, 野村秀洋洼か：縫合不全. 外
科治療 $37: 383-392,1977$

7）濱中良郎：消化管縫合不全の対策．とくに食道胃 扣よび食道空腸吻合法の工夫. 手術 $31: 783$ $-793,1977$

8) Irvin TT, Hunt TK: Reappraisal of the healing process of anastomosis of the colon. Surg Gyencol Obstet 138 : 741-746, 1974

9）戸塚守夫，早坂 滉：胃全摘術と器械吻合による 再健. 消外科 $7: 1210-1222,1984$

10）戸塚守夫, 早坂 滉：絴合不全の問題点と治愿. 消 外 $3: 261-268,1980$

11）上林純一, 芝 英一, 森 武貞 : 大量出血之凝固・ 線溶. 救急医 $8: 1443-1449,1984$

12）戸塚守夫, 早坂 滉: 重症感染症と DIC. 外科治療 $49: 433-441,1983$

13）丸山雄二：この症例に対する再手術適応の決定拉 よび術式の選択. 外科 $44: 33-38,1982$

14）高橋俊雄, 河野研一：腹腔内チ 合併症. 外科治療 $23: 1623-1626,1981$

15）森岡恭彦，玉熊正悦：術後消化管出血一とくに胃 切除縫合不全に合併した動脈性大出血について 一. 外科治療 $23: 1592-1595,1981$

16）三富利夫, 杉田輝也：消化管手術後の腹腔内出血 そその対策. 外科治療 $23: 1601-1605,1981$

17）大谷五良：術後腸管壊死の 3 例。外科治療 23 : $1620-1622,1981$

18) Williams LF, Anastasia LF, Hasiotis CA et al: Non occlusive mesenteric occlusion. Am J Surg $114: 376-381,1967$ 